\title{
Cardiovascular Pressor Reactivity After Chronic Converting Enzyme Inhibition
}

\author{
Michaela Bernasconi, Claudio Marone, Carlo Beretta-Piccoli, Giuseppe Lepori, Sidney Shaw, and \\ Peter Weidmann
}

In addition to inhibiting the formation of angiotensin II, chronic converting enzyme inhibition may affect other blood pressure modulating factors. The influence of an 8 week treatment phase with cilazapril on the activity of the renin-angiotensin-aldosterone and sympathetic nervous systems, the pressor reactivity to infused angiotensin II or norepinephrine, the chronotropic response to isoproterenol, and body sodium and plasma atrial natriuretic peptide concentrations was assessed in $\mathbf{1 1}$ normal subjects and 12 patients with essential hypertension. As compared to a 4 week placebo phase, cilazapril decreased arterial pressure in both study groups (from 124/83 $\pm 9 / 6$ to $114 / 77 \pm 9 / 5 \mathrm{~mm} \mathrm{Hg}$ and from $143 / 102 \pm 13 / 7$ to $137 / 96 \pm 10 / 10 \mathrm{~mm} \mathrm{Hg}$; $P<.025)$; exchangeable sodium $(-158 \mathrm{mmol}$ and, respectively, $-104 \mathrm{mmol}$ ) and upright plasma aldosterone $(-24 \%$ and $-15 \%)$ also tended to fall. Heart rate, the chronotropic response to posture or isoproterenol, plasma norepinephrine levels, the concentration/pressor response curve to norepinephrine, plasma atrial natriuretic peptide concentration, plasma angiotensin II and the responses of blood pressure or plasma aldosterone to angiotensin II were unchanged after 8 weeks of cilazapril.

Plasma renin activity increased $(+175 \%$ to $+650 \%)$.

These findings indicate that the blood pressure lowering effect of cilazapril in the stable phase of pharmacological intervention is not associated with modifications of sympathetic-dependent pressor reactivity or $\beta$-adrenergic sensitivity. Plasma angiotensin II concentration and angiotensin II-dependent pathways including the pressor and aldosterone responsiveness to angiotensin II are also unchanged. Am J Hypertens 1991;4:348-355

KEY WORDS: Cilazapril, angiotensin II, aldosterone, norepinephrine, essential hypertension.
$\mathrm{T}$ he use of inhibitors of converting enzyme has become an established principle of antihypertensive pharmacotherapy, but the mechanisms relating converting enzyme inhibition to a decrease of arterial pressure remain unclear. Reduction of circulating angiotensin II (AII) is the initial event. ${ }^{1}$ Under chronic conditions, the relationship between variations in arterial pressure and circulating AII

From the Ospedale Italiano, Viganello; Ospedale S. Giovanni, Bellinzona; and Medizinische Universitätspoliklinik Bern, Switzerland.

This work was supported by a grant in aid by Hoffman-La-Roche, Basle, Switzerland.

Address correspondance and reprint requests to Prof. Dr. med. C. Beretta-Piccoli, Ospedale Italiano di Lugano, 6962 Viganello, Switzerland. is less close, ${ }^{2}$ suggesting that additional mechanisms may be involved. Angiotensin II levels in tissues rather than in blood may determine arterial pressure. ${ }^{3}$ Accumulation of vasodilating kinins ${ }^{4}$ or prostaglandins ${ }^{5}$ may occur. Sympathetic-dependent cardiovascular regulation may be modified. ${ }^{6}$ Moreover, the plasma levels of a pressor hormone are inversely related to the cardiovascular pressor reactivity to them. ${ }^{7}$ Therefore, a decrease of circulating AII will result in a net depressor effect only in the absence of a full compensation by an incremented pressor sensitivity to AII.

After the introduction of the first oral acting converting enzyme inhibitor, captopril, more potent and longer acting substances, such as enalapril, were proposed for clinical use. ${ }^{8}$ Cilazapril, one of the newer substances, has the characteristics of a nonsulfhydryl prodrug, ie, 
after oral administration it is rapidly converted to the active metabolite, cilazaprilat. 9 Pharmacodynamic investigations in humans suggest that this drug is more potent and longer acting than both captopril and enalapril $^{10}$ and does not accumulate with repeated administration despite the long half-life. ${ }^{11}$ In order to investigate further the mechanism of action of chronic converting enzyme inhibition, this long-acting compound was chosen; its simultaneous effects on several blood pressure modulating systems including the pressor reactivity to angiotensin II or norepinephrine were evaluated in normal subjects and patients with essential hypertension.

\section{SUBJECTS AND METHODS}

Twenty-three subjects aged between 18 and 70 years were recruited for the study. They included 11 normal subjects (four women and seven men), aged 29 to 60 years (mean $\pm S D$ age $38 \pm 10$ years), and 12 patients with essential hypertension (four women and eight men), aged 26 to 58 years (mean age $45 \pm 12$ years) with a diastolic blood pressure between 95 and $115 \mathrm{~mm} \mathrm{Hg}$. The normal subjects were healthy volunteers without previous episodes of high blood pressure and with a blood pressure consistently $<140 / 90 \mathrm{~mm} \mathrm{Hg}$ throughout the study. The presence of hypertension in the patients was defined by obtaining repeated blood pressure measurements of between 140/90 and 180/115 mm $\mathrm{Hg}$, taken under outpatient conditions. Secondary forms of hypertension were excluded by the usual tests; no patient had malignant hypertension (hypertensive retinopathy stages III-IV), edema, arrhythmia, renal failure (serum creatinine $>95 \mu \mathrm{mol} / \mathrm{L}$ ) or heart failure. All antihypertensive drugs and potassium supplements were discontinued at least 3 weeks before the study began. None of the women was taking hormonal contraceptives. Informed consent was obtained from all subjects and the study protocol was approved by the ethical committee of our institution.

Treatment Plan The subjects were instructed to continue eating a normal diet, avoiding very high or low sodium intakes. ${ }^{12}$ A placebo (one tablet daily) was given over a period of 4 weeks and was then replaced by a 2.5 $\mathrm{mg}$ dose of cilazapril, given once daily at breakfast. After 2 weeks of treatment, the dose was increased to 5 $\mathrm{mg}$ daily if diastolic blood pressure was not decreased to $90 \mathrm{~mm} \mathrm{Hg}$. The duration of the whole treatment phase was 8 weeks.

\section{Blood Pressure, Hormones and Isoproterenol Test}

During therapy, subjects had their blood pressure and heart rate measured every 2 weeks, 24 to $26 \mathrm{~h}$ after their intake of the last cilazapril dose, between 7:00 and 9:00 $\mathrm{AM}$, after $10 \mathrm{~min}$ rest in the supine position and after $2 \mathrm{~min}$ in the standing position. During the 4 last days of the placebo and cilazapril treatment phases, the follow- ing measurements were obtained. A $24 \mathrm{~h}$ urine collection was carried out to determine sodium, potassium, and creatinine excretion rates. Blood pressure (standard cuff and sphygmomanometer; each value was the mean of three readings), heart rate, exchangeable sodium, and plasma sodium, potassium, calcium, phosphate, creatinine, uric acid, renin activity, angiotensin II (AII), aldosterone, norepinephrine (NE), epinephrine, and atrial natriuretic peptide (ANP) were determined after an overnight fast and after $1 \mathrm{~h}$ of rest in the supine position (subjects took only the usual morning dose of placebo or cilazapril). Blood pressure, heart rate, plasma renin activity, AII, aldosterone, NE, epinephrine, and ANP levels were measured again after the subjects had spent 60 min walking. After emptying the bladder, subjects rested in the supine position and an isoproterenol sensitivity test was performed with bolus injections according to our standard procedure. ${ }^{13,14}$

Norepinephrine and Angiotensin II Infusion In order to test the subjects' pressor or aldosterone responsiveness, NE and AII were infused intravenously 1 to 3 days after the isoproterenol test according to our standard procedure. ${ }^{13,14}$

Methodology Plasma and urinary sodium were measured by flame photometry. Creatinine, uric acid and calcium concentrations were measured by autoanalyzer, phosphate by colorimetric phosphomolybdate.

Plasma renin activity, aldosterone, AII, and ANP were determined by radioimmunoassay ${ }^{15-18}$ and plasma NE and epinephrine concentrations were obtained using a radioenzymatic method, ${ }^{19}$ as reported elsewhere. ${ }^{20}$ Exchangeable sodium was measured by isotope dilution technique using ${ }^{24} \mathrm{Na} .{ }^{21}$ Cardiovascular reactivity was analyzed by calculation of threshold and pressor doses ${ }^{13,14}$ and by deriving dose-response curves. The chronotropic isoproterenol dose was derived using the dose-response curve relating isoproterenol-induced increments of heart rate to the isoproterenol doses. ${ }^{22}$

Statistics Since the logarithmic transformation rather than the absolute values followed a Gaussian distribution, the natural logarithmic transformation of plasma renin activity, infused NE dosage, AII or isoproterenol and pressor or threshold NE and AII dosages, and chronotropic isoproterenol dosages were used for the statistical analysis. Statistical analysis included the paired Student's two-tailed $t$ test and the Wilcoxon test (comparison of paired values within groups), regression analysis, analyses of variance (comparison of values among the groups) and covariance (comparison of dose-response curves).

\section{RESULTS}

At the end of the placebo phase, normotensive and hypertensive subjects did not differ significantly in mean 
TABLE 1. CLINICAL AND BIOCHEMICAL FINDINGS BEFORE AND AFTER CILAZAPRIL IN NORMAL AND HYPERTENSIVE SUBJECTS (MEAN \pm SD)

\begin{tabular}{|c|c|c|c|c|}
\hline & \multicolumn{2}{|c|}{ Normal Subjects } & \multicolumn{2}{|c|}{ Essential Hypertension } \\
\hline & Placebo & Cilazapril & Placebo & Cilazapril \\
\hline \multicolumn{5}{|l|}{ Blood pressure, $\mathrm{mm} \mathrm{Hg}$} \\
\hline supine & $124 / 83 \pm 9 / 6$ & $114 / 77 \pm 9 / 5^{\dagger}$ & $143 / 102 \pm 13 / 7$ & $137 / 96 \pm 10 / 10^{*}$ \\
\hline upright & $120 / 86 \pm 14 / 8$ & $110 / 81 \pm 10 / 6^{*}$ & $141 / 110 \pm 13 / 8$ & $136 / 104 \pm 8 / 7^{*}$ \\
\hline \multicolumn{5}{|l|}{ Heart rate, beats $/ \mathrm{min}$} \\
\hline supine & $70 \pm 14$ & $67 \pm 7$ & $71 \pm 8$ & $71 \pm 10$ \\
\hline upright & $85 \pm 14$ & $88 \pm 12$ & $87 \pm 12$ & $82 \pm 12$ \\
\hline Body weight, kg & $73.1 \pm 12.3$ & $73.1 \pm 12.4$ & $75.5 \pm 11.6$ & $75.6 \pm 11.9$ \\
\hline Exchangeable sodium, mmol & $3140 \pm 507$ & $2982 \pm 497$ & $3008 \pm 436$ & $2904 \pm 440$ \\
\hline Haematocrit, \% & $41.5 \pm 3.85$ & $40.7 \pm 4.0$ & $42.7 \pm 5.2$ & $42.7 \pm 5.4$ \\
\hline Plasma sodium, mmol/L & $140.6 \pm 2.1$ & $140 \pm 1.8$ & $140.2 \pm 2.0$ & $140.5 \pm 2.3$ \\
\hline potassium, mmol/L & $3.95 \pm 0.27$ & $4.03 \pm 0.20$ & $4.12 \pm 0.25$ & $4.15 \pm 0.28$ \\
\hline calcium, $\mathrm{mmol} / \mathrm{L}$ & $2.34 \pm 0.08$ & $2.22 \pm 0.08$ & $2.36 \pm 0.09$ & $2.28 \pm 0.08$ \\
\hline phosphate, mmol/L & $1.17 \pm 0.13$ & $1.08 \pm 0.13$ & $1.01 \pm 0.16$ & $1.10 \pm 0.18$ \\
\hline uric acid, $\mu \mathrm{mol} / \mathrm{L}$ & $263 \pm 96$ & $279 \pm 107$ & $258 \pm 66$ & $298 \pm 68$ \\
\hline Creatinine clearance, $\mathrm{mL} / \mathrm{min}$ & $134 \pm 20$ & $137 \pm 34$ & $113 \pm 22$ & $111 \pm 31$ \\
\hline Urinary sodium, $\mathrm{mmol} / 24 \mathrm{~h}$ & $170 \pm 47$ & $172 \pm 39$ & $137 \pm 43$ & $151 \pm 59$ \\
\hline
\end{tabular}

${ }^{*} \mathrm{P}<.025 ; \uparrow \mathrm{P}<.01 \mathrm{v}$ placebo values.

age (38 $\pm 10 v 45 \pm 12$ years), body weight, exchangeable sodium, heart rate, plasma or urinary electrolytes, and creatinine clearance (Table 1).

The dose of cilazapril was increased after two treatment weeks in nine of 11 patients (mean dose $4.6 \pm$ $1.0 \mathrm{mg}$ ); in order to have a comparable dosage, the dose was also increased in six of the normal subjects (mean dose $3.8 \pm 1.3 \mathrm{mg}$ ).

As compared with the placebo phase, cilazapril decreased supine and upright arterial pressure in both study groups (Table 1). Heart rate, body weight, plasma and urinary electrolytes, and creatinine clearance were unchanged (Table 1). Exchangeable sodium tended to decrease, but in the individual groups the change did not reach statistical significance.

Renin-Angiotensin-Aldosterone System and Reactivity to AII As compared to placebo conditions, cilazapril caused a significant increase of supine and upright plasma renin activity and a fall of upright plasma aldosterone in the two study groups; supine plasma aldosterone decreased only in hypertensives (Table 2). Plasma AII levels remained on average unchanged (Table 2).

As compared to placebo conditions, supine, preinfusion plasma AII did not change significantly after cilazapril in the two study groups while plasma aldosterone

TABLE 2. RENIN-ANGIOTENSIN-ALDOSTERONE SYSTEM AND REACTIVITY TO ANGIOTENSIN II BEFORE AND AFTER CILAZAPRIL (MEAN \pm SD)

\begin{tabular}{|c|c|c|c|c|}
\hline & \multicolumn{2}{|c|}{ Normal Subjects } & \multicolumn{2}{|c|}{ Essential Hypertension } \\
\hline & Placebo & Cilazapril & Placebo & Cilazapril \\
\hline \multicolumn{5}{|l|}{ Plasma Reinin Activity, $\mathrm{ng} / \mathrm{mL} \cdot \mathrm{h}$} \\
\hline supine & $1.78 \pm 0.7$ & $7.69 \pm 5.92^{\dagger}$ & $1.81 \pm 1.31$ & $4.95 \pm 3.94^{\dagger}$ \\
\hline upright & $5.29 \pm 2.03$ & $31.54 \pm 20.48^{\dagger}$ & $4.20 \pm 2.76$ & $31.4 \pm 34.5^{\dagger}$ \\
\hline \multicolumn{5}{|l|}{ Plasma Angiotensin II, pg/mL } \\
\hline supine & $6.1 \pm 3.6$ & $6.6 \pm 2.0$ & $8.7 \pm 3.7$ & $8.8 \pm 4.7$ \\
\hline upright & $13.1 \pm 7.9$ & $9.9 \pm 3.2$ & $16.3 \pm 10.6$ & $13.9 \pm 7.6$ \\
\hline \multicolumn{5}{|l|}{ Plasma Aldosterone, ng/dL } \\
\hline supine & $7.2 \pm 2.9$ & $6.2 \pm 1.5$ & $7.8 \pm 2.1$ & $6.2 \pm 1.5^{*}$ \\
\hline upright & $13.1 \pm 7.9$ & $9.9 \pm 3.2^{*}$ & $16.3 \pm 10.6$ & $13.9 \pm 7.6^{*}$ \\
\hline Preinfusion plasma angiotensin II, $\mathrm{pg} / \mathrm{mL}$ & $7.7 \pm 4.5$ & $8.3 \pm 1.9$ & $10.5 \pm 2.4$ & $8.5 \pm 3.6$ \\
\hline Angiotensin II threshold dose, $\mathrm{ng} / \mathrm{kg} \cdot \min$ & $1.12 \pm 0.56$ & $1.57 \pm 1.45$ & $0.83 \pm 0.33$ & $0.90 \pm 0.62$ \\
\hline Angiotensin II pressor dose, $\mathrm{ng} / \mathrm{kg} \cdot \min$ & $12.12 \pm 6.5$ & $8.92 \pm 5.13$ & $6.33 \pm 2.4$ & $7.0 \pm 4.2$ \\
\hline
\end{tabular}

\footnotetext{
${ }^{*} \mathrm{P}<.05 ; \dagger P<.005 \mathrm{v}$ placebo.
} 
tended to fall slightly although not significantly (Figure 1). After placebo, the pressor reactivity, as judged by the AII pressor and threshold doses, was slightly, but not significantly, lower in hypertensive than in normal subjects and did not change after cilazapril in the two study groups (Table 2). After placebo, in normal subjects, the increase in systolic blood pressure during AII infusion at the dose rate of $10 \mathrm{ng} / \mathrm{kg} \cdot \min (+22 \pm 12 \mathrm{~mm} \mathrm{Hg})$ was associated with a significant $(P<.005)$ decrease of heart rate $(-9 \pm 8$ beats $/ \mathrm{min})$; in patients with essential hypertension the AII-induced increase of systolic blood pressure $(+31 \pm 11 \mathrm{~mm} \mathrm{Hg})$ was not accompanied by a decrease of heart rate $(-1 \pm 6$ beats $/ \mathrm{min})$. The relationship between AII-induced increases in blood pressure and concomitant decrements of heart rate differed significantly between the two study groups $(\mathrm{F}=21.2$; $P<.01)$. After cilazapril, heart rate decreased during AII infusion in normal (+26 $\pm 14 \mathrm{~mm} \mathrm{Hg}$ and $-10 \pm 6$ beats/min) and hypertensive subjects $(+29 \pm 16 \mathrm{~mm}$ $\mathrm{Hg}$ and $-6 \pm 4$ beats $/ \mathrm{min} ; P<.01)$ and the relationship between AII-induced increments of blood pressure and decrements of heart rate did not differ between the two study groups $(\mathrm{F}=0.48)$.

The plasma AII levels measured at the end of each AII infusion dose rate correlated closely with the corresponding dose rate; the correlation was similar after placebo and cilazapril in normal subjects (respectively: $\mathrm{r}=0.87 ; P<.001 ; \ln y=0.99 \ln \mathrm{x}+2.76$, and $\mathrm{r}=0.87$; $P<.001 ; \ln y=0.99 \ln x+2.89)$ and hypertensive patients $(\mathrm{r}=0.77 ; P<.001 ; \ln \mathrm{y}=0.89 \ln \mathrm{x}+3.20$ and $\mathrm{r}=0.87 ; P<.001 ; \ln y=1.06 \ln x+2.82)$. The relationship between the AII-induced increases in diastolic arterial pressure and plasma AII concentrations was not modified by cilazapril as compared with placebo conditions $(\mathrm{F}=2.07$ and 1.86; $P=\mathrm{NS}$ ) (Figure 1).

After placebo, AII caused a significant increase of plasma aldosterone in normal subjects and patients with essential hypertension (Figure 1). After cilazapril, the plasma levels of aldosterone increased to a comparable extent during AII infusion in normal subjects and in hypertensive patients. The relationship between plasma aldosterone and plasma AII concentration obtained

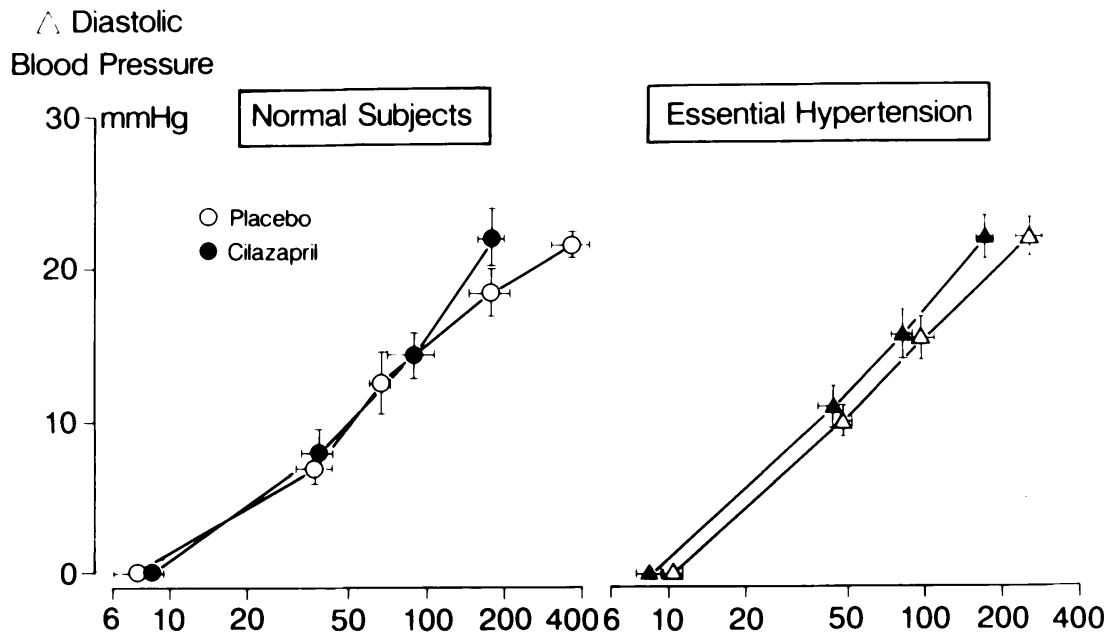

Plasma Aldosterone

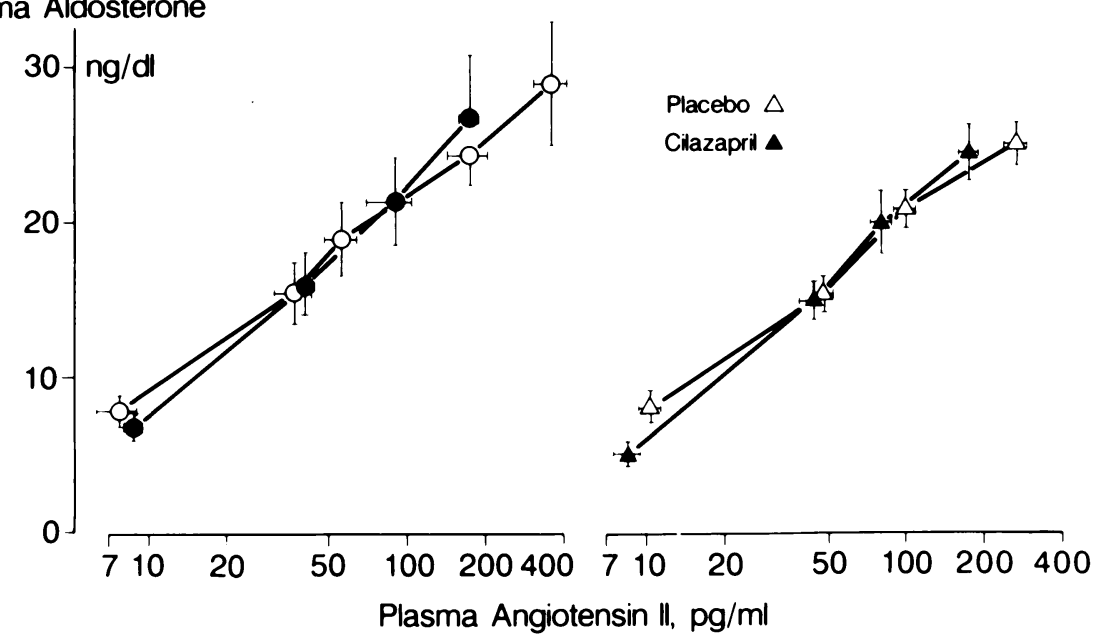

FIGURE 1. Relationship between diastolic blood pressure or plasma aldosterone and plasma angiotensin II during angiotensin II infusion before and after cilazapril in normal subjects (left panel) and patients with essential hypertension (right panel). Open symbols indicate mean values after placebo; black symbols mean values after cilazapril. Bars indicate SEM. The curves are not significantly different. 
during AII infusion was not modified by cilazapril as compared to placebo conditions in the two study groups ( $F=0.03$ and 0.86 ; NS) (Figure 1).

Sympathetic Nervous System At the end of the placebo phase, normal subjects and patients with essential hypertension did not differ significantly in supine and upright plasma NE and epinephrine levels as well as in NE threshold and pressor doses (Table 3). Cilazapril did not modify either plasma NE and epinephrine levels or the pressor reactivity to infused NE, as judged by the NE threshold and pressor doses (Table 3).

Under placebo conditions, the increase in systolic blood pressure during $\mathrm{NE}$ infusion at the dose of $200 \mathrm{ng} / \mathrm{kg} \cdot \min$ was associated with a significant decrease of heart rate in normal subjects $(+30 \pm 8 \mathrm{~mm} \mathrm{Hg}$ and $-8 \pm 6$ beats $/ \mathrm{min} ; P<.01)$. Hypertensive patients responded to a lower $\mathrm{NE}$ dose rate $(100 \mathrm{ng} / \mathrm{kg} \cdot \mathrm{min})$ with a comparable increase of arterial pressure and decrease of heart rate $(+33 \pm 9 \mathrm{~mm} \mathrm{Hg}$ and $-6 \pm 5$ beats $/ \mathrm{min} ; P<.025)$. After cilazapril, the NE-induced increase in mean blood pressure was accompanied by a similar decrease of heart rate in the two study groups $(+33 \pm 10 \mathrm{~mm} \mathrm{Hg}$ and $-8 \pm 6$ beats $/ \mathrm{min}$ and $+36 \pm$ $14 \mathrm{~mm} \mathrm{Hg}$ and $-5 \pm 4$ beats/min, respectively). The relationship between the NE-induced increases in arterial pressure and the concomitant decrements of heart rate did not differ between normal and hypertensive subjects under placebo conditions and it was unaffected by cilazapril $(\mathrm{F}=0.06$ to 0.46$)$.

Plasma NE concentration, measured at the end of each NE infusion step, correlated closely with the corresponding NE infusion rates and correlations were similar in normal subjects before $(r=0.94 ; \ln y=0.83 \ln x+$ $1.5 ; P<.001)$ and after $(\mathrm{r}=0.98 ; \ln \mathrm{y}=0.93 \ln \mathrm{x}+1.09$; $P<.001)$ cilazapril; the corresponding correlations were also comparable in hypertensive patients $(r=$ $0.92 ; \ln y=0.83 \ln x+1.49 ; \quad P<.001$ and $\mathrm{r}=0.94$; $\ln y=0.91 \ln x+1.21 ; P<.001)$. The concentrationresponse curve of arterial pressure and plasma NE concentration was not modified by cilazapril in the two study groups as compared to placebo conditions (Figure 2) $(\mathrm{F}=1.44$ and 2.95).

Atrial Natriuretic Peptide At the end of the placebo phase, supine and upright plasma ANF levels were lower $(P<.05)$ in normal subjects $(27.5 \pm 19.4$ and $18.6 \pm 16.0 \mathrm{pg} / \mathrm{mL}$ ) than in hypertensive patients $(52.5 \pm 28.5$ and $38.3 \pm 20.5 \mathrm{pg} / \mathrm{mL})$. There was no change after cilazapril, with a persistent elevation in hypertensives $(30.5 \pm 21.3$ and $19.8 \pm 13.3 \mathrm{pg} / \mathrm{mL}$ in normal subjects $v 62.5 \pm 39.1$ and $34.3 \pm 15.1 \mathrm{pg} / \mathrm{mL}$ in hypertensive patients).

Sensitivity to Isoproterenol Chronotropic effects of isoproterenol, as judged by the mean threshold and chronotropic doses, were comparable between normal and hypertensive subjects $(0.3 \pm 0.3$ and $1.6 \pm 1.5 \mu \mathrm{g} v$ $0.2 \pm 0.2$ and $1.8 \pm 1.3 \mu \mathrm{g})$. Both variables were unchanged after cilazapril $(0.4 \pm 0.7$ and $1.3 \pm 1.1 \mu \mathrm{g}$ in normal subjects, $0.2 \pm 0.2$ and $2.0 \pm 1.5 \mu \mathrm{g}$ in hypertensive patients) (Figure 3).

With respect to dose-response curves, the heart rateisoproterenol relationships were similar in normal and hypertensive subjects after placebo (Figure 3). After cilazapril, the dose-response curve was slightly, nonsignificantly displaced to the right in normal subjects ( $\mathrm{F}=$ $3.47 ; P=\mathrm{NS}$ ) and was unchanged in hypertensives $(\mathrm{F}=0.002 ; P=\mathrm{NS})$.

Side Effects Side effects were not reported by normal and hypertensive subjects, except for the report of mild cough by one healthy man. The hematological and biochemical control parameters did not change during the study, except for a transient slight increase of the serum aspartate and alanine aminotransferase in one normal subject.

TABLE 3. PLASMA CATECHOLAMINES AND NOREPINEPHRINE INFUSION BEFORE AND AFTER CILAZAPRIL (MEAN $\pm S D$ )

\begin{tabular}{|c|c|c|c|c|}
\hline & \multicolumn{2}{|c|}{ Normal Subjects } & \multicolumn{2}{|c|}{ Essential Hypertension } \\
\hline & Placebo & Cilazapril & Placebo & Cilazapril \\
\hline \multicolumn{5}{|l|}{ Plasma Norepinephrine, $\mathrm{ng} / \mathrm{dL}$} \\
\hline supine & $21.2 \pm 6.4$ & $19.3 \pm 6.7$ & $23.8 \pm 9.5$ & $24 \pm 9$ \\
\hline upright & $41.9 \pm 13.7$ & $34.8 \pm 7.4$ & $41.4 \pm 17$ & $50.7 \pm 24.5$ \\
\hline \multicolumn{5}{|l|}{ Plasma Epinephrine, ng/dL } \\
\hline supine & $3.1 \pm 1.6$ & $2.9 \pm 2.2$ & $3.5 \pm 3.3$ & $3.5 \pm 3.2$ \\
\hline upright & $6.6 \pm 3.9$ & $5.0 \pm 2.8$ & $6.0 \pm 4.1$ & $7.4 \pm 6.8$ \\
\hline Preinfusion plasma angiotensin II, $\mathrm{pg} / \mathrm{mL}$ & $8.7 \pm 5.0$ & $7.1 \pm 2.2$ & $10.4 \pm 3.0$ & $8.0 \pm 2.5$ \\
\hline Preinfusion plasma norepinephrine, ng/dL & $20.5 \pm 9.8$ & $18.4 \pm 2.8$ & $24 \pm 9.1$ & $24.4 \pm 7.7$ \\
\hline Norepinephrine threshold dose, $\mathrm{ng} / \mathrm{kg} \cdot \min$ & $51 \pm 79$ & $48 \pm 39$ & $25 \pm 14$ & $33 \pm 35$ \\
\hline pressor dose, $\mathrm{ng} / \mathrm{kg} \cdot \min$ & $143 \pm 58$ & $190 \pm 79$ & $163 \pm 80$ & $206 \pm 205$ \\
\hline
\end{tabular}




\section{$\Delta$ Mean Blood Pressure}

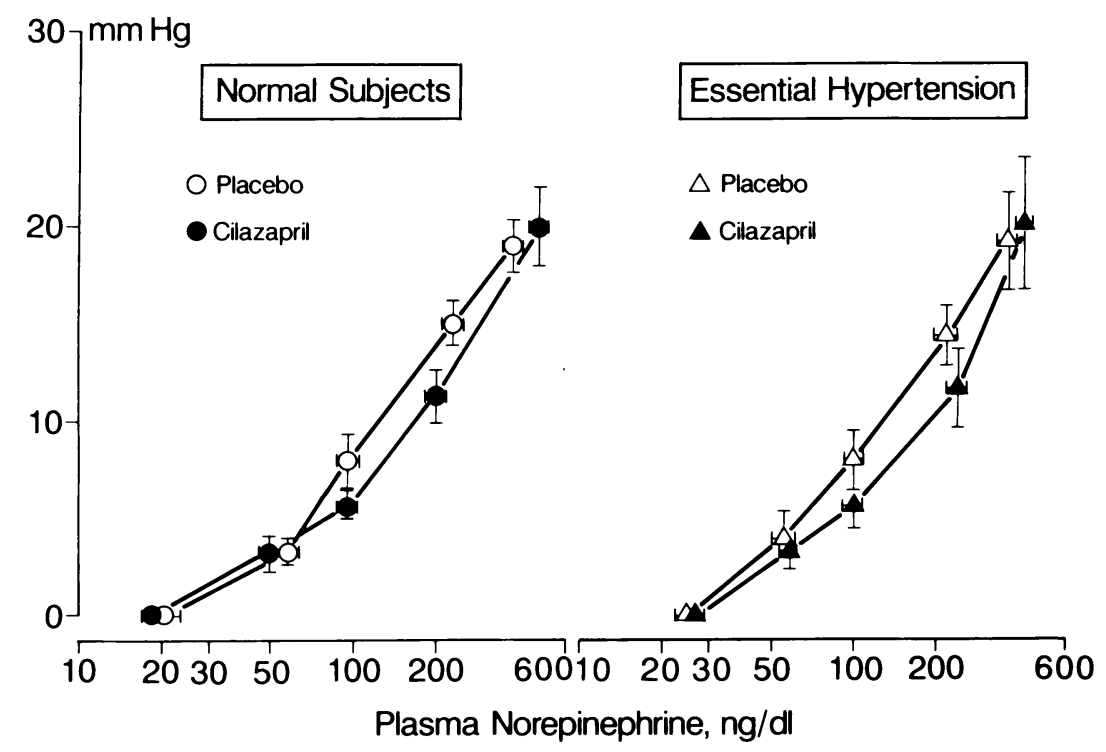

FIGURE 2. Relationship between mean blood pressure and plasma norepinephrine during norepinephrine infusion before and after cilazapril in normal subjects (left panel) and patients with essential hypertension (right panel). Open symbols indicate mean values after placebo; black symbols mean values after cilazapril. Bars indicate SEM. The curves are not significantly different.

\section{DISCUSSION}

The findings of the present study indicate that the blood pressure lowering effect of an 8 week converting enzyme inhibition with the long acting compound cilazapril was not accompanied by modifications of the physiological relationship between the endogenous noradrenergic activity and the cardiovascular pressor reac-

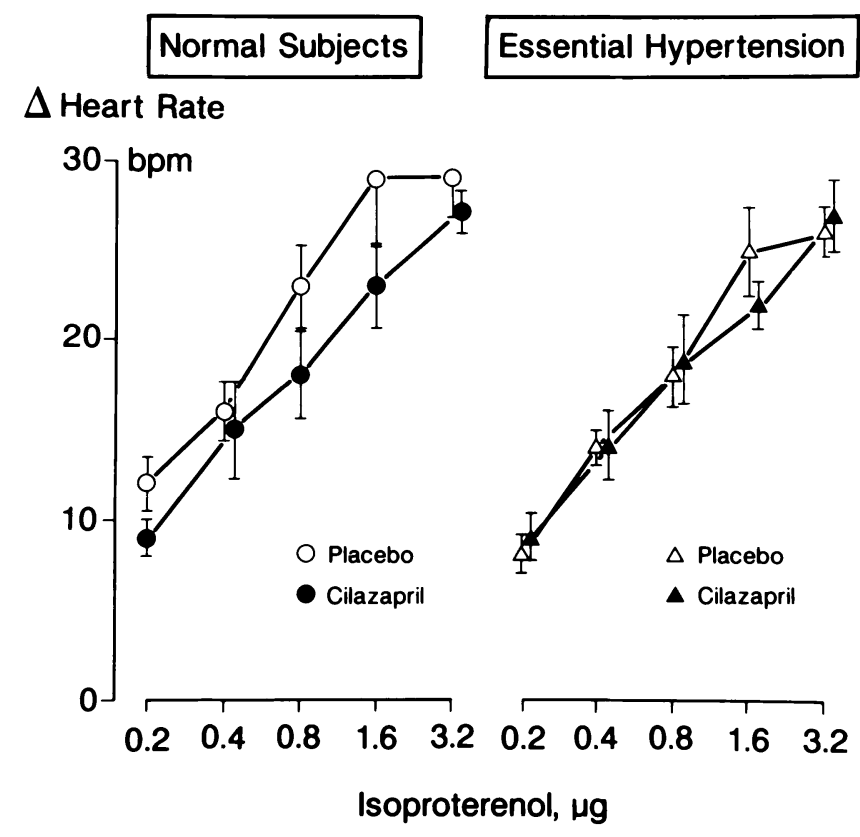

FIGURE 3. Dose response curves for isoproterenol-induced increases in heart rate before and after cilazapril in normal subjects (left panel) and patients with essential hypertension (right panel). Open symbols indicate mean values after placebo; black symbols mean values after cilazapril. Bars indicate SEM. The curves are not significantly different. tivity to NE. Despite concomitant renin activation and aldosterone suppression, as indices of effective converting enzyme inhibition, two angiotensin II-dependent pathways, the cardiovascular pressor reactivity and the adrenal release of aldosterone, were unaltered. Plasma levels of ANF were also unchanged. On the other hand, a tendency for suppressed plasma aldosterone and body sodium depletion may identify two contributory factors in the hypotensive mechanism of converting enzyme inhibition.

Cilazapril, given for 8 weeks, significantly decreased arterial pressure in both normal and hypertensive subjects, without modification of the heart rate, the chronotropic response to assumption of the upright posture, isoproterenol injection or, as demonstrated in a previous study, to exercise. ${ }^{23}$ The decrease of heart rate during acute, NE-induced elevation of arterial pressure was also unchanged, pointing to an unaltered baroreflex sensitivity. In our hypertensive patients, the bradycardic response to AII infusion was found to be blunted after placebo and normal after cilazapril. The meaning of this observation is unclear. A dissociation between a normal heart rate responsiveness to NE and a blunted response to AII is not a feature of hypertensive patients and was not observed previously in our laboratory. ${ }^{13}$ On the other hand, cilazapril did not alter the heart rate response to AII in normal subjects, despite the significant decrease of arterial pressure. In single dose studies, cilazapril did not modify heart rate, sympathetic nervous activity and baroreflex sensitivity, but enhanced parasympathetic activity, ${ }^{24}$ suggesting a withdrawal of the vagolytic actions of AII. Similar findings were reported after administration of other compounds such as captopril or enalapril, ${ }^{14,25}$ indicating a similar cardiovascular profile for these compounds. 
Noradrenergic activity and pressor reactivity to NE did not change in both normal and hypertensive subjects after cilazapril. Plasma NE and epinephrine levels were reported to be unchanged after captopril ${ }^{26,27}$ or enalapril. ${ }^{28}$ The pressor effects to infused NE, studied after short-term converting enzyme blockade (up to 2 weeks) was noted to be blunted ${ }^{29}$ or unchanged ${ }^{30,31} \mathrm{~A}$ limited sensitivity of the pressor response curves without concomitant measurements of the plasma NE concentration could, at least partly, explain these discrepancies. After more prolonged treatment, the pressor reactivity remained unchanged in normal subjects but in patients with essential hypertension a decrease of the slope of the pressor response curve to NE was reported.$^{28}$ In the latter investigation, the blunted pressor reactivity to NE emerged only at very high concentrations of plasma NE, while at physiological or moderately elevated levels the responsiveness of blood pressure to NE was normal.

Body sodium, measured in patients with essential or renovascular hypertension, was reported to be unchanged after captopril or enalapril. ${ }^{1,8}$ In contrast, a slight decrease was reported in 16 hypertensive patients treated for 6 weeks with enalapril. ${ }^{28}$ In the present study, exchangeable sodium tended to decrease in both normal and hypertensive subjects. It appears possible that a decrease of plasma aldosterone may have influenced sodium metabolism. However, a fall in plasma aldosterone was not observed in all studies with converting enzyme inhibitors, since after suppression in the early phase, plasma aldosterone tends to rise in the chronic phase of treatment. ${ }^{32}$ This pattern of adrenal response may reflect the complex regulation of aldosterone secretion, since in addition to AII, other modulating factors such as sodium and potassium balance are potentially influenced by converting enzyme inhibition. ${ }^{1}$

The profile of the renin-angiotensin-aldosterone system after cilazapril was characterized by unchanged AII levels, a markedly stimulated plasma renin activity, and a tendency for decreased plasma aldosterone concentration. The failure to detect a persistent decrement of circulating AII during chronic converting enzyme inhibition with cilazapril or other compounds ${ }^{28}$ may be at least partly related to crossreactivity of high angiotensin I levels in the radioimmunoassay of AII. ${ }^{1}$ On the other hand, activation of angiotensin I may partly overcome the competitive inhibition of converting enzyme. ${ }^{33}$ The association of unchanged plasma AII levels and decreased plasma aldosterone levels may support the possibility of a dissociation in the renin-angiotensin-aldosterone axis. This may reflect the partly different regulation of the two hormones and has been reported under other circumstances, such as a rapid change in dietary sodium intake. ${ }^{34}$ Unchanged plasma AII levels were associated with unchanged pressor and adrenal responses to AII. Thus, it would appear that after chronic converting enzyme inhibition the renin-angiotensin system may be able to recover, at least partly, a physiological acute regulation of the pressor and aldosterone regulating pathways. This may also imply that under these circumstances the AII receptor number and the receptor-agonist affinity are not modified. Previous data in the literature are consistent with this hypothesis; after acute blockade with converting enzyme there is an acute fall of plasma AII with an enhanced response of blood pressure or plasma aldosterone to infused AII. ${ }^{29,31}$ Under more chronic conditions, 1 to 8 weeks of treatment with captopril, the pressor reactivity to AII was not modified. ${ }^{14,35}$ After 6 weeks of treatment with enalapril, the acute aldosterone response to infused AII was unchanged in normal and hypertensive subjects. ${ }^{28}$

Plasma ANF concentration were significantly elevated in the present group of patients with essential hypertension. This could not be explained by differences in age or renal function. Cilazapril did not alter plasma ANF levels in the two study groups. This suggests that cilazapril is an effective antihypertensive agent, with a cardiovascular profile comparable to that of other available converting enzyme inhibitors. Its mechanism of action may be partly related to sodium depletion and aldosterone suppression, but not to modifications of sympathetic-dependent pressure regulation, atrial natriuretic peptide concentration, or AII dependent pathways for acute blood pressure or aldosterone regulation.

\section{ACKNOWLEDGMENTS}

We acknowledge the technical assistance of Gudrun Haueter, Ruth Mosimann, Elisabeth Oldenberg, Stephanie Schwenk, Ritva Takkinen, and Jane Boden, and the secretarial assistance of Daniela Lazzaretti.

\section{REFERENCES}

1. Atkinson $\mathrm{AB}$, Morton JJ, Brown JJ, et al: Captopril in clinical hypertension. Changes in components of reninangiotensin system and in body composition in relation to fall in blood pressure with a note on measurement of angiotensin II during converting enzyme inhibition. $\mathrm{Br}$ Heart J 1980;44:290-296.

2. Waeber B, Brunner HR, Brunner DB, et al: Discrepancy between antihypertensive effect and angiotensin converting enzyme inhibition by captopril. Hypertension 1980;2:236-242.

3. Johnston CI, Mendelsohn FAO, Cubela RB, et al: Inhibition of angiotensin converting enzyme (ACE) in plasma and tissues: studies ex vivo after administration of ACE inhibitors. J Hypertens 1988;6(suppl 3):S17-S22.

4. Johnston $\mathrm{CL}$, Clappison BH, Anderson WP, Yasujiman $\mathrm{M}$ : Effect of angiotensin converting enzyme inhibition on circulating local kinin levels. Am J Cardiol 1982;49:1401-1404.

5. Swartz SL: The role of prostaglandins in mediating the 
effects of angiotensin converting enzyme inhibitors and other antihypertensive drugs. Cardiovasc Drugs Ther 1987;1:39-43.

6. Antonaccio MJ, Kerwin L: Pre- and post-junctional inhibition of vascular sympathetic function by captopril in spontaneously hypertensive rats. Hypertension 1981;3(suppl 1):154-162.

7. Philipp T, Distler A, Cordes U: Sympathetic nervous system and blood pressure control in essential hypertension. Lancet 1978;ii:959-963.

8. Bauer JH, Gaddy P: Effects of enalapril alone, and in combination with hydrochlorothiazide, on renin-angiotensin-aldosterone, renal function, salt and water excretion, and body fluid composition. Am J Kidney Dis $1985 ; 6: 222-232$.

9. Natoff IL, Nixon JS, Francis RJ, et al: Biological properties of the angiotensin-converting enzyme inhibitor cilazapril. J Cardiovasc Pharmacol 1985;7:569-580.

10. Francis RJ, Brown AN, Kler L, et al: Pharmacokinetics of the converting enzyme inhibitor cilazapril in normal volunteers and the relationship to enzyme inhibition: development of a mathematical model. J Cardiovasc Pharmacol 1987;9:32-38.

11. Shionoiri H, Gotoh E, Takagi N, et al: Antihypertensive effects and pharmacokinetics of single and consecutive doses of cilazapril in hypertensive patients with normal and impaired renal function. J Cardiovasc Pharmacol 1988;11:242-249.

12. Weidmann $P$, Beretta-Piccoli $C$, Ziegler WH, et al: Age versus urinary sodium for judging renin, aldosterone and catecholamine levels: studies in normal subjects and patients with essential hypertension. Kidney Int 1978;14:619-628.

13. Weidmann $P$, Beretta-Piccoli C, Link L, et al: Cardiovascular conterregulation during sympathetic inhibition in normal subjects and patients with mild hypertension Hypertension 1983;5:873-880.

14. Beretta-Piccoli C, Ziegler WH, Antonini P, et al: Cardiovascular regulation during converting enzyme inhibition with captopril in diabetes-associated hypertension. J Hypertens 1990;8:671-678.

15. Sealey JE, Gerten-Banes J, Laragh JH: The renin system: variations in man measured by radioimmunoassay. Kidney Int 1972;1:240-253.

16. Düsterdieck GO, McElwee G: Estimation of angiotensin II concentration in human plasma by radioimmunoassay: some applications to physiological and clinical states. Eur J Clin Invest 1971;2:32-38.

17. Malvano R, Gandolfi C, Gianessi D, et al: Radioimmunoassay of aldosterone in crude plasma extracts. J Nucl Biol Med 1976;20:37-44.

18. Weidmann $P$, Gnädinger MP, Ziswiler HR, et al: Cardiovascular, endocrine and renal effects of atrial natriuretic pepetide in essential hypertension. J Hypertens 1986;4(suppl 2):S71-S83.

19. Da Prada $M$, Zürcher G: Simultaneous radioenzymatic determination of plasma and tissue adrenaline, noradrenaline and dopamine within the fentomole range. Life Sci 1976;19:1161-1174.

20. Beretta-Piccoli C, Weidmann P, Boehringer K, et al: Relationship between plasma aldosterone and angiotensin
II before and after noradrenergic inhibition in normal subjects and patients with mild essential hypertension. J Clin Endocrinol Metab 1984;59:316-320.

21. Beretta-Piccoli C, Weidmann P: Body sodium-blood volume state in non-azotemic diabetes mellitus. Miner Electrolyte Metab 1982;7:36-47.

22. Cleaveland CR, Rango RE, Shand DG: A standardized isoproterenol sensitivity test. Arch Intern Med 1972;130:47-52.

23. White WB, McCabe EJ, Hager WD, Schulman P: The effects of the long-acting angiotensin-converting enzyme inhibitor cilazapril on casual, exercise, and ambulatory blood pressure. Clin Pharmacol Ther 1988;173178.

24. Elliott HL, Ajayi AA, Ried JL: The influence of cilazapril on indices of autonomic function in normotensives and hypertensives. Br J Clin Pharmacol 1989;27:3035-3075.

25. Ried JL, Millar HA, Campbell BC: Enalapril and autonomic reflexes and exercise performance. J Hypertens 1983;1(suppl 1):129-134.

26. Niarchos AP, Pickering TG, Morganti A, Laragh JH: Plasma catecholamines and cardiovascular responses during converting enzyme inhibition in normotensive and hypertensive man. Clin Exp Hypertens [A] 1982;4:761 - 789.

27. Muiesan G, Alicandri CL, Agabiti-Rosei A, et al: Angiotensin-converting enzyme inhibition, catecholamines and hemodynamics in essential hypertension. Am J Cardiol 1982;49:1420-1424.

28. Uehlinger D, Ferrier $C$, Weidmann $P$, et al: Antihypertensive contribution of sodium depletion and the sympathetic axis during chronic angiotensin II converting enzyme inhibition. J Hyperten 1989;7:901-907.

29. Imai $Y$, Abe $K$, Seino $M$, et al: Attenuation of pressor responses to norepinephrine and pitressin and potentiation of pressor response to angiotensin II by captopril in human subjects. Hypertension 1982;4:444-451.

30. Vierhapper $H$, Witte PV, Waldhäusl W: Unchanged pressor effect of norepinephrine in normal man following the oral administration of two angiotensin converting enzyme inhibitors, captopril and HOE 498. J Hypertens 1986;4:9-11.

31. Koletsky RJ, Gordon MB, LeBoff MS, et al: Captopril enhances vascular and adrenal responsiveness to angiotensin II in essential hypertension. Clin Sci 1984;66:299-305.

32. Staessen J, Lijnen P, Fagard R, et al: Rise of plasma aldosterone during long-term captopril treatment (letter). New Engl J Med 1981;304:1110.

33. Giese J, Rasmussen S, Nielsen MD, Ibsen M: Biochemical monitoring of vasoactive peptides during angiotensin converting enzyme inhibition. J Hypertens 1983;1(suppl 1):31-36.

34. Rogacz S, Williams GH, Hollenberg NK: Time courses of enhanced adrenal responsiveness to angiotensin on a low salt diet. Hypertens 1990;15:376-380.

35. Fruncillo J, Rotmensch $\mathrm{HH}$, Vlasses $\mathrm{PH}$, et al: Effect of captopril and hydrocholorothiazide on the response to pressor agents in hypertensives. Eur J Clin Pharmacol 1985;28:5-9. 